\title{
Corrosion resistance and protective properties of chromium coatings electrodeposited from an electrolyte based on deep eutectic solvent
}

\author{
V.S.Protsenko ${ }^{1}$, L.S.Bobrova ${ }^{1}$, S.A.Korniy ${ }^{2}$, \\ A.A.Kityk ${ }^{1}$, F.I.Danilov ${ }^{1}$ \\ ${ }^{1}$ Ukrainian State University of Chemical Technology, \\ 8 Gagarin Ave., 49005 Dnipro, Ukraine \\ ${ }^{2}$ G.Karpenko Physico-Mechanical Institute, National Academy of Sciences \\ of Ukraine, 5 Naukova St., 79060 Lviv, Ukraine
}

Received April 16, 2018

\begin{abstract}
The paper deals with the corrosion resistance and protective properties of chromium coatings electrodeposited from an electrolyte based on deep eutectic solvent, a new generation of ionic liquids. The electroplating bath contained chromium (III) chloride, choline chloride and some extra water. Chromium layers with a thickness of 2.5, 5, 10, 15 and $20 \mu \mathrm{m}$ were deposited on mild steel samples and their corrosion and electrochemical behavior was determined by voltammetry method and electrochemical impedance spectroscopy technique. It was stated that the highest resistance to corrosion damage of the $\mathrm{Cr}$ layer and mild steel substrate is achieved when the thickness of deposit is about $5 \mu \mathrm{m}$. At smaller or greater thickness, the chromium electrodeposits become more defective, and a larger number of microcracks and micropores appear; as a result, the corrosion stability and protective characteristics diminish.
\end{abstract}

Keywords: deep eutectic solvents; electrodeposition; trivalent chromium; coating; corrosion resistance; protective properties.

Рассматриваются коррозионная стойкость и защитные свойства хромовых покрытий, электроосажденных из электролита на основе низкотемпературного эвтектического растворителя - нового поколения ионных жидкостей. Электролит содержал хром (III) хлорид, холин хлорид и определенное количество дополнительно введенной воды. Хромовые покрытия с толщиной $2,5,5,10,15$ и 20 мкм осаждены на образцы из малоуглеродистой стали, их коррозионное и электрохимическое поведение охарактеризовано вольтамперометрическим методом и методом измерения электродного импеданса. Установлено, что наивысшая устойчивость к коррозионному разрушению слоев $\mathrm{Cr}$ и стальной основы достигается, когда толщина осадка близка к 5 мкм. При меньшей или большей толщине гальванические покрытия становятся более дефектными и появляется большое количество микротрещин и микропор, в результате чего коррозионная стойкость и защитные свойства ослабляются.

Корозійна стійкість і захисні властивості хромових покриттів, електроосаджених із електроліту на основі низькотемпературного евтектичного розчинника. В.С.Проценко, Л.С.Боброва, С.А.Корній, А.А.Кітик, Ф.Й.Данилов.

Розглядаються корозійна стійкість та захисні властивості хромових покриттів, електроосаджених із електроліту на основі низькотемпературного евтектичного розчинника - нового покоління іонних рідин. Електроліт містив хром (III) хлорид, холін хлорид та певну кількість додатково введеної води. Хромові покриття з товщиною 2,5, $5,10,15$ і 20 мкм осаджено на зразки 3 маловуглецевої сталі, їх корозійну й елект- 
рохімічну поведінку охарактеризовано вольтамперометричним методом та методом вимірювання електродного імпедансу. Встановлено, що найвища стійкість до корозійного руйнування Cr шарів та сталевої основи досягаються, коли товщина осаду близька до 5 мкм. При меншій або більшій товщині гальванічні покриття стають більш дефектними і з'являється велика кількість мікротріщин та мікропор, у результаті чого корозійна стійкість та захисні властивості послаблюються.

\section{Introduction}

Electrochemical systems based on deep eutectic solvents (DESs) attract nowadays close attention due to such their advantages as high conductivity, wide electrochemical windows, low-toxicity, negligible vapor pressure, non-flammability, compatibility with water, easy preparation and maintenance, biodegradability and biocompatibility [1-5]. DESs are considered as a new and very promising type of ionic liquids [1]. DESs constitute a powerful tool in the preparation of innovative materials with well-defined and appropriate functional properties, by safe and efficient procedures [5]. The replacement of water and organic solvents as well as conventional ionic liquids by these unique mixtures in different fields of research and industry, especially in electrochemistry and electroplating, is definitely expected to become an increasingly common practice.

Among a large number of different metals which can be electrodeposited from DESs based electrolytes, chromium occupy a special place due to its wide application as a unique decorative, hard, anti-wear and protective coating [6-8].

The development of eco-friendly $\mathrm{Cr}$ (III) electroplating baths as an alternative to highly toxic industrial Cr(VI) electroplating is a key problem in modern surface engineering [9-12]. Chromium is not easy to deposit from aqueous solutions based on trivalent chromium salts due to the complex aqueous solution chemistry of Cr(III) ions compounds [7]. In this regard, DESs based Cr(III) plating baths look very promisingly.

Thus, DESs based Cr(III) electroplating electrolyte can be prepared by mixing choline chloride and hydrated chromium (III) chloride in the molar ratio of 1 to 2 , respectively [3]. This mixture is a viscous liquid at ambient temperature (its freezing point is $286.9 \mathrm{~K}$ [3] while choline chloride and chromium (III) chloride melt at $573 \mathrm{~K}$ and $356 \mathrm{~K}$, respectively).

Although a number of papers have been published that reported $\mathrm{Cr}$ electrodeposition using DESs [3, 13-20], the corrosion resistance and protective properties of $\mathrm{Cr}$ coatings obtained from DESs based plating baths remain practically unexplored. Only two papers $[15,19]$ characterized the corrosion behavior of the $\mathrm{Cr}$ layers electrodeposited from non-aqueous deep eutectic solvent-based electrolytes. However, the influence of the thickness of deposits on the corrosion and protective properties was not investigated, although the thickness of $\mathrm{Cr}$ deposits is known to be a crucial factor determining the rate of electrochemical corrosion of coatings and substrate in a corrosive environment.

Therefore, this work was aimed to investigate these important characteristics of chromium electrodeposits by means of voltammetry method and electrochemical impedance spectroscopy (EIS) technique. We studied the effect of the thickness of $\mathrm{Cr}$ coatings deposited on steel substrate on their corrosion stability and protective performance in a chloride acidic corrosive medium.

\section{Experimental}

Although the eutectic mixture is formed at a composition of $1: 2$ (mol.) choline chloride $/ \mathrm{CrCl}_{3} \cdot 6 \mathrm{H}_{2} \mathrm{O}[3,13]$, we electrodeposited chromium films from a liquid mixture containing choline chloride, chromium (III) chloride and water in 2.5:1:12 molar ratios, respectively (an optimized bath composition suggested in previous report [16]). The procedure of bath preparation was described in detail elsewhere [21, 22]. Water was added to the DES to increase the conductivity and decrease the viscosity of fluid. It should be emphasised that the specified amount of water indicates the total amount of $\mathrm{H}_{2} \mathrm{O}$ in the system, both originating from hexahydrate salt $\mathrm{CrCl}_{3} \cdot 6 \mathrm{H}_{2} \mathrm{O}$ and extra water added to the mixture.

Chromium was deposited on a diskshaped sample of mild steel $\left(S=1.77 \mathrm{~cm}^{2}\right)$ fixed in a plastic holder. Prior to each experiment, the surface of mild steel substrate was polished by $0.05 \mu \mathrm{m}$ aluminia slurry, then treated by $\mathrm{HCl}$ aqueous solution (1:1 vol.) and thoroughly rinsed with distillate water. The electrodeposition was performed at a constant current density of $5 \mathrm{~A} \cdot \mathrm{dm}^{-2}$ and a temperature of $40^{\circ} \mathrm{C}$. Platinum gauze was used in all experiments as 


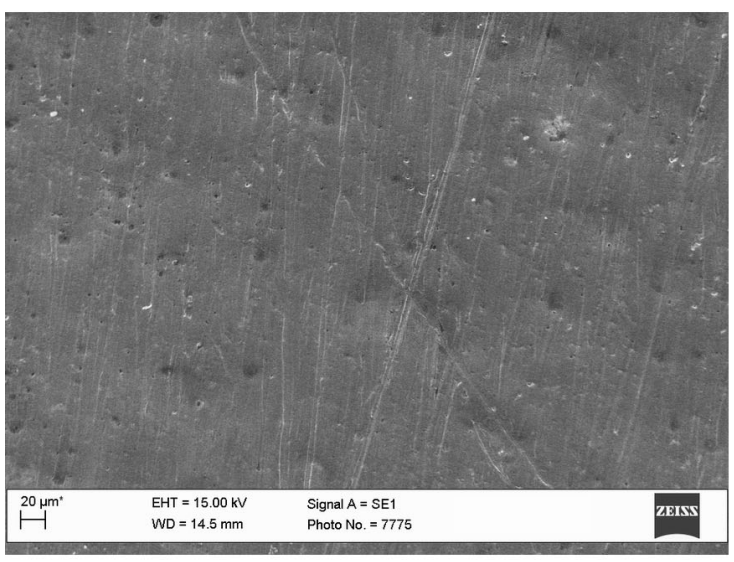

a)

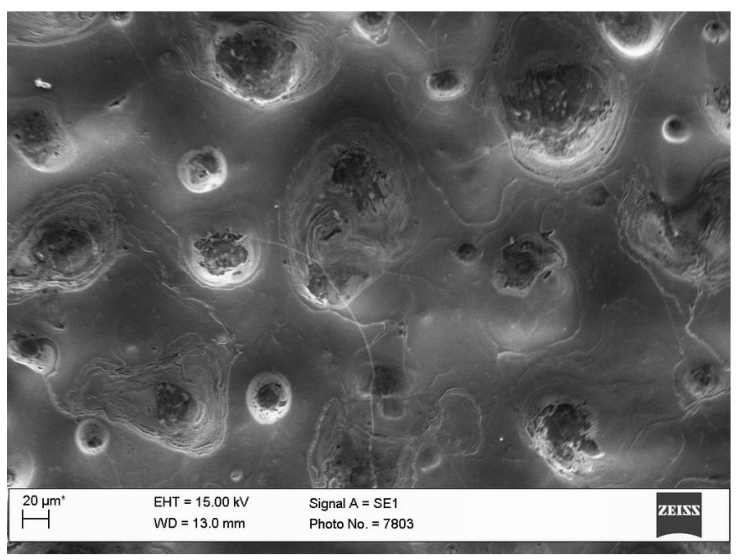

c)

an anode without separation of anodic and cathodic compartments. The current efficiency of chromium deposition reaction and the thickness of deposits were calculated based on gravimetric measurements.

The surface morphology of $\mathrm{Cr}$ coatings was investigated by scanning electron microscopy (Zeiss EVO 40XVP) in secondary electron regime. The chemical composition of the surface layers was controlled by energy dispersive X-ray spectroscopy (EDX) coupled with SEM microscope (Oxford INCA Energy 350).

The corrosion resistance and protective properties of the electrodeposited chromium coatings were studied by means of voltammetry and electrochemical impedance spectroscopy using $0.1 \mathrm{~N} \mathrm{Na}_{2} \mathrm{SO}_{4}$ aqueous solution (its $\mathrm{pH}$ value was adjusted to 3 by the addition of $\mathrm{H}_{2} \mathrm{SO}_{4}$ ) as a corrosive medium. The temperature was maintained at $25^{\circ} \mathrm{C}$. Electrochemical experiments were carried out using a Potentiostat/Galvanostat Reference 3000 (Gamry, USA). The ohmic potential drop was automatically compensated by the built-in iR-compensator of the poten-

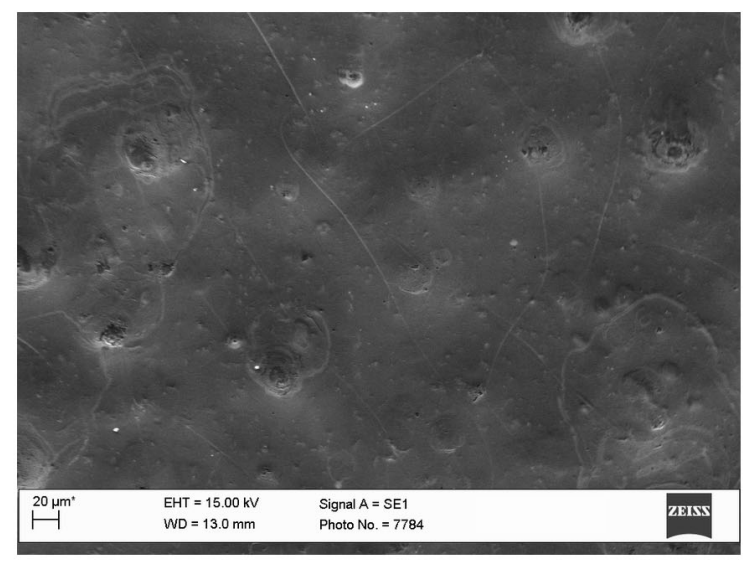

b)

Fig. 1. SEM images of the surface of chromium coatings with a thickness of $2.5 \mu \mathrm{m}$ (a), $5 \mu \mathrm{m}$ (b), and $20 \mu \mathrm{m}$ (c).

tiostat. A common thermostatted glass three-electrode cell was used in which the electrode compartments were separated by a glass porous diaphragm. Dissolved atmospheric oxygen was removed by purging purified electrolytic hydrogen. The counter electrode was porous graphite, its surface area considerably exceeded the overall surface area of the working electrode. The working electrode was immersed in a test solution for approximately $20 \mathrm{~min}$ prior to each electrochemical test in order to establish a stable open circuit potential (OCP).

The potential sweep rate in voltammograms was $50 \mathrm{mV} \cdot \mathrm{s}^{-1}$. Electrochemical impedance spectra were recorded at open circuit potentials in the frequency range of $0.01 \mathrm{~Hz}$ to $100 \mathrm{kHz}$ with constant AC voltage amplitude of $5 \mathrm{mV}$. The data of EIS were treated (the development of electrical equivalent circuits and the determination of quantitative parameters of their elements) using Gamry Elchem Analyst software. 


\section{Results and discussion}

The typical SEM images of the surface of electrodeposited chromium are presented in Fig. 1. It is seen that the surface morphology of a $2.5 \mu \mathrm{m}$ thick coating is characterized by a number of imperfections: there are micropores and microcracks on the surface. EDX analysis of this electrodeposit shows the presence of such elements as $\mathrm{Cr}$, $\mathrm{O}$ and $\mathrm{Fe}$ (Fig. 2a). The detection of $\mathrm{Cr}$ and $O$ on oxidized chromium surface is naturally expected. A weak peak of $\mathrm{Fe}$ (ca. 2.25 at. $\%$ ) indicates that there are through pores in coatings which partly expose steel substrate. It should be noted that a signal of $\mathrm{Fe}$ in EDX spectrum vanishes when the deposits become thicker (Fig. 2b). That means that through pores disappear with increasing thickness of coatings. However, some crater-like defects (cavities) can be observed on the surface (see Fig. 1b, c). The formation of craters may be due to hydrogen evolution occurring together with metal electrodeposition. Since the viscosity of the plating electrolyte is still high [21,22], the withdrawal of hydrogen gas bubbles evolved on the cathode is impeded; they remain on the electrode surface for some time and partially block it. When a $\mathrm{Cr}$ layer is growing around hydrogen bubbles, cavities are formed on the coating surface. It is clear that increasing average deposits thickness (i.e. increasing electrolysis duration) leads to the expansion of the cavities on the surface and makes the surface more heterogeneous. In addition, the quantity of microcracks seems to become larger with increasing the deposits thickness.

Evidently, the presence of microcracks, micropores and craters as well as the changes in their quantity and size should affect the corrosion resistance and protective properties of chromium coatings.

As follows from data shown in Fig. 3, anodic dissolution of steel in a corrosive environment used in this work proceeds in a relatively wide range of potentials and the current peak corresponds to the electrode potentials of about $0 \div 0.4 \mathrm{~V}$. The presence of $\mathrm{Cr}$ electrodeposits suppresses the current of anodic dissolution of steel substrate. At the same time, it is known that no current peaks of anodic dissolution of chromium are observed in voltammograms in solutions with the used $\mathrm{pH}$ value [23]. Thus, the corrosion degradation of chromium occurs in passive state, whereas steel dissolves through pores in active state. Hence, one
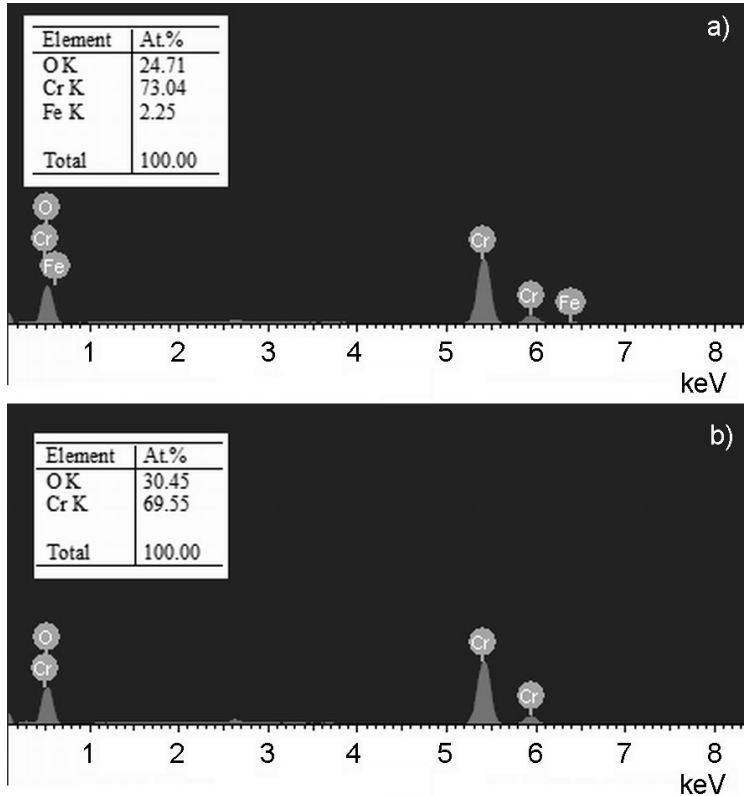

Fig. 2. EDX spectra of the surfaces showed in Fig. 1 corresponding to the coatings with a thickness of $2.5 \mu \mathrm{m}$ (a) and $5 \mu \mathrm{m}$ (b).

can neglect the rate of $\mathrm{Cr}$ dissolution as compared with that of a steel substrate. Then the degree of protection (DP) can be determined using the following equation:

$$
D P=\frac{I_{s}-I}{I_{s}} \cdot 100 \% \text {, }
$$

where $I_{s}$ is the maximum current of anodic dissolution of a steel sample without any coating and $I$ is the maximum current of anodic dissolution of a steel sample with a chromium coating (dissolution in the pores of the coating).

The calculated degree of protection as a function of deposits thickness is given in Table 1. It is seen that the DP value is about $56 \%$ at a $\mathrm{Cr}$ deposit thickness of $2.5 \mu \mathrm{m}$, such a relatively low value may be explained by a large amount of uncovered area of steel (in micropores and microckracks) subjected to the influence of corrosive medium. The degree of protection grows approaching ca. $98 \%$ at a $\mathrm{Cr}$ thickness of $5 \mu \mathrm{m}$, this is obviously due to decreasing the porosity of protective chromium deposits. However, a further increase in coatings thickness results in gradual degradation of protective properties which can be associated with the deterioration of surface morphology and structure of $\mathrm{Cr}$ deposits (that means increasing quantity of through microckracks and micropores). 
Table 1. The degree of protection as a function of deposits thickness

\begin{tabular}{|c|c|}
\hline $\begin{array}{c}\text { Chromium deposits } \\
\text { thickness }(\mu \mathrm{m})\end{array}$ & DP $(\%)$ \\
\hline 2.5 & 55.8 \\
5 & 97.5 \\
10 & 94.1 \\
15 & 86.4 \\
20 & 78.3 \\
\hline
\end{tabular}

Although voltammetry technique provides simple and intuitive way to evaluate the degree of protection, it is not perfect enough. The maximum currents of the anodic dissolution of steel are measured at potentials which are far from actual corrosion potentials (OCP). In addition, voltammetric method is a destructive test and the coatings and substrate can undergo changes during electrode potential sweep which may somewhat distort the measured results.

In order to obtain comprehensive data on the kinetics of corrosion process, the electrochemical impedance spectroscopy method was used. It is known that EIS is a very sensitive, informative and non-destructive tool which allows obtaining reliable and detailed data on the kinetics of various kinds of electrochemical processes, including corrosion processes.

The Nyquist diagrams of deposits plated from DES based chromium plating bath are shown in Fig. 4. For the sake of comparison, the impedance spectrum of the steel substrate without any coatings is also given. The impedance plot of steel exhibits depressed semicircle which implies that the rate of the electrochemical process is determined by the charge transfer step and occurs on inhomogeneous surface [23]. A close inspection of the Nyquist diagrams of $\mathrm{Cr}$ deposits reveals that the impedance spectra consist of two depressed semicircles for each sample electrodeposit, although they are not well resolved. Similar impedance spectra were previously observed in case of $\mathrm{Cr}$ coatings subjected to corrosion in sulfuric acid solution [24]. We think that this behavior is associated with two simultaneous corrosion reactions and both of them are controlled by the charge transfer and proceed on inhomogeneous electrode surface. The first reaction is the anodic dissolution of chromium deposit, the second one is the reaction of steel substrate dissolution through pores in the coatings.

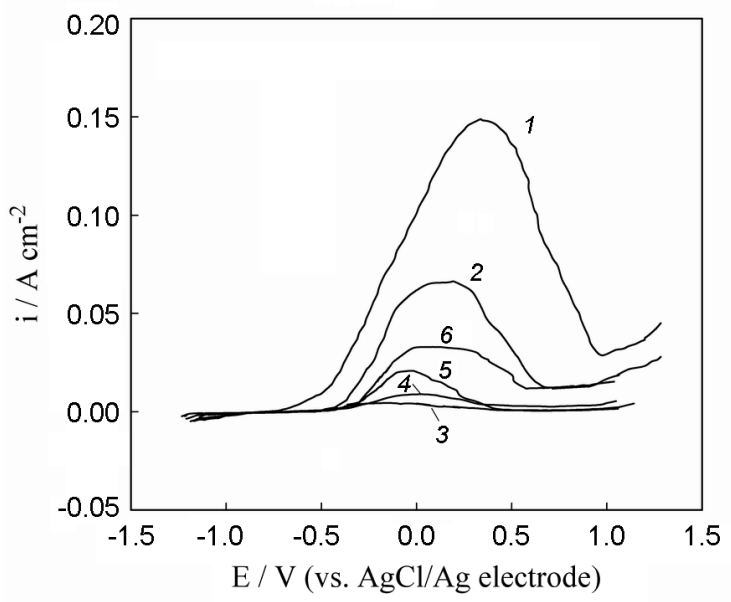

Fig. 3. Voltammograms of a steel sample (1) and steel samples coated with chromium layers with a thickness of $2.5 \mu \mathrm{m}(2), 5 \mu \mathrm{m}(3)$, $10 \mu \mathrm{m}(4), 15 \mu \mathrm{m}(5)$ and $20 \mu \mathrm{m}(6)$.

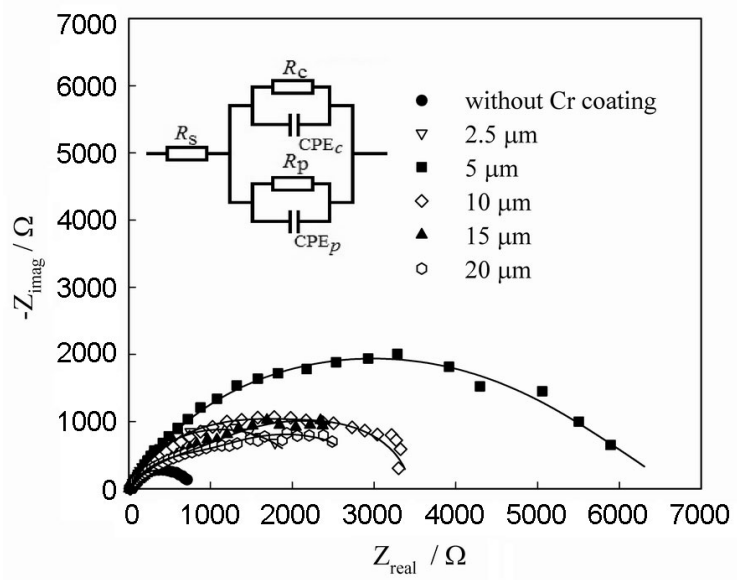

Fig. 4. Nyquist diagrams recorded for mild steel sample (1) and $\mathrm{Cr}$ coatings on mild steel substrate (2-6) in $0.1 \mathrm{~N} \mathrm{Na}_{2} \mathrm{SO}_{4}(\mathrm{pH}$ 3) at OCP. The thickness of chromium coatings was $2.5 \mu \mathrm{m}$ (2), $5 \mu \mathrm{m}$ (3), $10 \mu \mathrm{m}$ (4), $15 \mu \mathrm{m}$ (5) and $20 \mu \mathrm{m}(6)$. In the inset: Electrical equivalent circuit modeling impedance of electrode/solution interface.

To interpret the obtained results, we developed an electrical equivalent circuit showed in the inset in Fig. 4. This equivalent circuit includes the following elements: ohmic resistance of solution $\left(R_{s}\right)$; polarization resistances of the reactions of chromium dissolution $\left(R_{c}\right)$ and steel substrate dissolution through pores $\left(R_{p}\right)$; constant phase elements characterising the interface of "chromium deposit/solution" $\left(\mathrm{CPE}_{\mathrm{c}}\right)$ and "steel substrate in the deposit pores/solution" $\left(\mathrm{CPE}_{\mathrm{p}}\right)$. It should be noted that the elements, related to the reactions of corrosion 
Table 2. The calculated electrochemical impedance parameters of the corrosion of chromium coatings and steel substrate

\begin{tabular}{|c|c|c|c|c|c|c|c|}
\hline \multirow{2}{*}{$\begin{array}{c}\text { Chromium } \\
\text { deposits } \\
\text { thickness } \\
(\mu \mathrm{m})\end{array}$} & \multirow[t]{2}{*}{$R_{s}(\Omega)$} & \multicolumn{3}{|c|}{$\begin{array}{c}\text { Characteristics of corrosion of } \mathrm{Cr} \\
\text { deposits }\end{array}$} & \multicolumn{3}{|c|}{$\begin{array}{c}\text { Characteristics of corrosion of steel } \\
\text { substrate through pores }\end{array}$} \\
\hline & & $R_{c}\left(\Omega \cdot \mathrm{cm}^{2}\right)$ & $\begin{array}{c}Q_{c} \times 10^{6} \\
\left(\Omega^{-1} \cdot s^{n} \cdot \mathrm{cm}^{-2}\right)\end{array}$ & $n_{c}$ & $R_{p}\left(\Omega \cdot \mathrm{cm}^{2}\right)$ & $\begin{array}{c}Q_{p} \times 10^{3} \\
\left(\Omega^{-1} \cdot s^{n} \cdot \mathrm{cm}^{-2}\right)\end{array}$ & $n_{p}$ \\
\hline $\begin{array}{l}\text { (steel } \\
\text { substrate) }\end{array}$ & 10.5 & - & - & - & 748 & 2010 & 0.650 \\
\hline 2.5 & 10.5 & 940 & 1180 & 0.675 & 2199 & 4.09 & 0.700 \\
\hline 5 & 10.0 & 5050 & 39 & 0.959 & 3595 & 0.73 & 0.998 \\
\hline 10 & 10.3 & 2310 & 200 & 0.807 & 3100 & 2.5 & 0.997 \\
\hline 15 & 10.4 & 1010 & 680 & 0.795 & 2500 & 2.9 & 0.800 \\
\hline 20 & 10.2 & 950 & 780 & 0.755 & 2200 & 3.9 & 0.500 \\
\hline
\end{tabular}

dissolution of the coating and substrate, are connected in the equivalent circuit in parallel but not in series that conforms to the principle of independent occurrence of concurrent electrode processes.

The introduction of constant phase elements into the electrical equivalent circuits is associated with the energy and geometric heterogeneity of the electrode surface [25]. The impedance of the constant phase element is given by the following formula:

$$
Z_{C P E}=\left[Q(j \omega)^{n}\right]^{-1},
$$

in which $Q$ is a constant, $j=\sqrt{-1}$ is the imaginary unit, $\omega=2 \pi f$ is the angular frequency in rad:s ${ }^{-1}$ ( $f$ is the frequency in hertz), and $n$ is the dimensionless empirical exponent corresponding to phase deviation.

The experimental data in Fig. 4 are displayed as symbols and the continuous lines are obtained by curves fitting using the adapted equivalent circuit. The calculated kinetic parameters are summarized in Table 2 .

As follows from the data given in Table 2 , the maximum polarization resistance of chromium electrochemical dissolution is observed at the deposit thickness of $5 \mu \mathrm{m}$ indicating the highest corrosion resistance. At a smaller thickness $(2.5 \mu \mathrm{m})$ or at increasing the thickness (10 $\mu \mathrm{m}$ and more), the polarization resistance appreciably diminishes. The changes in $R_{c}$ values well correlate with the proper changes in $n$ value. It is known that the exponent $n$ assumes its values in the range of from 0.5 (porous electrode) to 1 (ideally planar electrode) [25]. The higher the parameter $n$, the greater is the extent of energy and geometric heterogeneity and roughness of the electrode. In addition, $Q_{c}$ values in Eq. (1) are often associated with the surface area available for the electrochemical reaction [26]. It is clear from the obtained data that the smallest surface area is related to the $\mathrm{Cr}$ coatings with the thickness of $5 \mu \mathrm{m}$. Thus, the most uniform and the least developed $\mathrm{Cr}$ electrode surface corresponds to the highest corrosion stability. All these conclusions well agree with the estimation of the effect of the deposits thickness on the heterogeneity of surface morphology (see above).

The polarization resistance of the electrochemical corrosion of steel substrate $\left(R_{p}\right)$ increases if a chromium layer has been deposited which can be explained by the reduction of "free" steel surface exposed to the action of the corrosive medium. This correlates with the changes in values of $Q_{p}$. Evidently, the electrochemical dissolution of a steel substrate occurs only in through pores and cracks in the electrodeposits. As was stated by SEM observations and is confirmed by EIS measurements, the least quantity of micropores and microcracks is typical of the coatings with the thickness of $5 \mu \mathrm{m}$. This thickness of deposits is correlated to the highest degree of protection (that means the highest value of $R_{p}$ ). At smaller and greater thickness the number of microdefects in deposits increases and the degree of protection is expectedly reduced.

\section{Conclusions}

In conclusion, it should be noted that the use of DES-based chromium plating baths allows avoiding the numerous problems of aqueous solutions of Cr(III) ions [4, 7, 16]. As a result of wider electrochemical window, such systems ensure higher current efficiency (i.e. higher deposition rates) that "common" aqueous chromium electrolytes 
[21, 27]. In addition, DES-based Cr(III) plating baths provide electrodepositing not only thin "decorative" $\mathrm{Cr}$ films but also thicker layers (industrial "hard" chromium electrodeposition).

The influence of the thickness of $\mathrm{Cr}$ coatings electrodeposited from DES-based Cr(III) plating bath on their corrosion resistance and protective characteristics has been investigated for the first time in this work. It was established that the best results (i.e. the highest resistance to corrosion damages of the $\mathrm{Cr}$ layer and mild steel substrate) are achieved if the thickness of deposits is closed to some intermediate value (the degree of protection of ca. $98 \%$ at a $5 \mu \mathrm{m}$ thick coating). At lower or greater thickness, the chromium electrodeposits become more defective, and a larger number of microcracks and micropores appear resulting in a decrease in corrosion stability and protective performance. These findings should be taken into consideration in the further development of chromium electroplating processes based on deep eutectic solvents.

\section{References}

1. E.L.Smith, A.P.Abbott, K.S.Ryder et al., Chem.Rev., 114, 11060 (2014).

2. A.P.Abbott, K.J.McKenzie, Phys.Chem.Chem. Phys., 8, 4265 (2006).

3. A.P.Abbott, K.S.Ryder, U.Konig, Trans.Inst. Met. Finish., 86, 196 (2008).

4. A.P.Abbott, G.Frisch, K.S.Ryder, Annu.Rev. Mater. Res., 43, 335 (2013).

5. L.I.N.Tome, V.Baiao, W.da Silva et al., Appl. Mater. Today, 10, 30 (2018).

6. A.Liang, Y.Li, H.Liang et al., Mater.Lett., 189, 221 (2017).
7. S.Surviliene, O.Nivinskiene, A.Cesuniene et al., J.Appl. Electrochem., 36, 649 (2006).

8. V.Protsenko, F.Danilov, Electrochim.Acta, 54, 5666 (2009).

9. V.S.Protsenko, V.O.Gordiienko, F.I.Danilov et al., Surf. Eng., 27, 690 (2011).

10. F.I.Danilov, V.S.Protsenko, V.O.Gordiienko et al., Appl.Surf.Sci., 257, 8048 (2011).

11. V.S.Protsenko, F.I.Danilov, Clean Technol. Environ. Policy, 16, 1201 (2014).

12. V.S.Protsenko, V.O.Gordiienko, F.I.Danilov, Electrochem.Commun., 17, 85 (2012).

13. A.P.Abbott, G.Capper, D.L.Davies et al., Chem.A Europ.J., 10, 3769 (2004).

14. A.P.Abbott, A.A.Al-Barzinjy, P.D.Abbott et al., Phys.Chem.Chem. Phys., 16, 9047 (2014).

15. J.Maharaja, M.Raja, S.Mohan, Surf. Eng., 30, 722 (2014).

16. E.S.C.Ferreira, C.M.Pereira, A.F.Silva, $J$. Electroanal. Chem., 707, 52 (2013).

17. D.C.McCalman, L.Sun, Y.Zhang et al., $J$. Phys. Chem. B, 119, 6018 (2015).

18. L.Sun, J.F.Brennecke, Ind.Eng. Chem.Res., 54, 4879 (2015).

19. J.L.Zhang, C.D.Gu, Y.Y.Tong et al., $R S C$ Adv., 5, 71268 (2015).

21. L.S.Bobrova, F.I.Danilov, V.S.Protsenko, J. Mol. Liq., 223, 48 (2016).

22. V.S.Protsenko, L.S.Bobrova, F.I.Danilov, Ionics, 23, 637 (2017).

23. F.I.Danilov, V.S.Protsenko, A.A.Kityk, Prot. Met.Phys. Chem.Surf., 50, 672 (2014).

24. L.Sziraki, E.Kuzmann, K.Papp et al., Mater. Chem. Phys., 133, 1092 (2012).

25. U.Rammelt, G.Reinhard, Electrochim.Acta, 35, 1045 (1990).

26. P.Najafi Sayar, M.E.Bahrololoom, J.Appl. Electrochem., 39, 2489 (2009).

27. V.S.Protsenko, L.S.Bobrova, A.S.Baskevich et al., J.Chem. Technol. Metall., 53, 906 (2018). 